Arkadiusz Luboń

\title{
POEZJA WCIĄŻ UWIKLANA NAJNOWSZE TEUMACZENIA LIRYKI RUDYARDA KIPLINGA NA TLE JEJ WCZEŚNIEJSZEJ RECEPCJI PRZEKŁADOWEJ W POLSCE
}

Znajomość poezji Rudyarda Kiplinga wśród czytelników polskojęzycznych określić można mianem marginalnej, wybiórczej i fragmentarycznej. Choć za życia noblisty wydano pięć - nie licząc wierszy ogłaszanych okazjonalnie w brytyjskiej prasie oraz strof wchodzących oryginalnie w obręb tekstów prozatorskich - tomów jego liryki (Departmental Ditties, Barrack-Room Ballads, The Seven Seas, The Five Nations i The Years Between), to za sprawą niewielkiej liczby poetyckich przekładów nazwisko Kiplinga jest w Polsce utożsamiane przede wszystkim $\mathrm{z}$ twórczością powieściopisarską i nowelistyczną. I ona jednak postrzegana jest nader stereotypowo, jako zdominowana albo przez teksty dydaktyczne i rozrywkowe, kierowane głównie do dzieci, albo też przez utwory motywowane interesem politycznym Zjednoczonego Królestwa, które usprawiedliwiały i nadal usprawiedliwiają aktualność etykiety „barda imperializmu", stosowanej wobec niego, jak zauważa Marek Zaleski, przez „znakomitą większość autorów opracowań krytycznych”. Z jednej więc strony, jak ujmuje to Antonina Łuszczykiewicz, pisarz ten jest na gruncie polskim „nieco zapomniany, a czytelnicy kojarzą z jego nazwiskiem w zasadzie tylko Księgę dżungli i postać sympatycznego Mowgliego”. Z drugiej zaś, spopularyzowane w ostatnich dekadach XX wieku badania postkolonialne kreślą i upowszechniają sylwetkę Kiplinga jako naczelnego

${ }^{1}$ M. Zaleski, Kipling i Conrad: spojrzenie z dwóch kątów imperium, „Res Publica Nowa” 2005, nr 4, s. 82. 
„psalmisty szowinizmu” budzącego „oburzenie z powodu zawartej w jego utworach ideologii” . „Twórczość niewielu chyba pisarzy, którzy znaleźli się w kanonie literackim” - konkluduje Joanna Kokot - „została równie silnie podporządkowana stereotypom odbiorczym, jak twórczość Rudyarda Kiplinga”"

Opinię Kai Bogomilskiej z połowy lat 90., iż „polski czytelnik, jeśli chce czegoś dowiedzieć się o Kiplingu, musi korzystać przede wszystkim z opracowań obcojęzycznych"4, wprawdzie można uznać za już w pewnej mierze przedawnioną, ale jedynie w odniesieniu do prozatorskiej części dorobku pisarza. Rodzime studia literaturoznawcze bowiem w przeważającej większości proponują refleksję nad opowiadaniami noblisty, jedynie wzmiankując o jego obfitej twórczości poetyckiej ${ }^{5}$. Oczywisty wpływ na taki kształt i ukierunkowanie polskich badań wywiera

2 A. Łuszczykiewicz, „Psalmista szowinizmu”. Rudyard Kipling wobec Indii i Indusów, Silva Rerum, Poznań 2014, s. 11.

3 J. Kokot, Takie sobie „bajeczki”. Gry z czytelnikiem w nowelistyce R. Kiplinga, Wydawnictwo Gdańskie, Gdańsk 1993, s. 7. Jak dodaje autorka: „niezamierzonym rezultatem badań literackich, a szczególnie krytyki literackiej, bywa niekiedy tworzenie stereotypów czy też schematów modelowych, które nałożone na określony tekst z pozoru w pełni go wyjaśniają, eliminując z pola widzenia czytelnika wszystko to, co wykracza poza schemat (a być może nawet mu przeczy). Klisze te są powielane i utrwalane w świadomości literackiej (czy raczej kulturowej) przez takie teksty, jak na przykład popularne historie literatury, podręczniki szkolne bądź skrypty uniwersyteckie, popularne wykłady i odczyty lub też niekiedy wstępy i posłowia do utworów literackich. Mogą one nieraz zdominować odbiór wypowiedzi artystycznych, spłycając doświadczenie całej złożoności zjawiska, jakie w istocie taka wypowiedź stanowi”.

4 K. Bogomilska, Rudyard Kipling - twórca omamiony imperializmem, „Gazeta Polska” 1996, nr 3, s. 16.

5 Znamienny przykład stanowi rozprawa Rudyard Kipling wobec Indii i Indusów $\mathrm{z}$ adnotacją: „w niniejszej pracy autorka koncentruje się głównie na twórczości prozatorskiej Kiplinga, która stanowi doskonały materiał do badań nad światopoglądem pisarza [...]. Przebogaty dorobek poetycki, jaki po sobie pozostawił, bez wątpienia zasługiwałby na osobną, dokładną analizę, w związku z czym w dysertacji znalazły się odniesienia tylko do najważniejszych jego wierszy” (A. Łuszczykiewicz, „Psalmista szowinizmu”..., s. 11). 
nie tylko znikoma liczba dostępnych przekładów liryki brytyjskiego twórcy, ale często także ich rozproszenie, brak skompilowania w jednym tomie oraz daleko posunięta fragmentaryczność: w języku polskim funkcjonują nierzadko jedynie wyimki z różnych utworów. Co szczególne, wiele z tekstów uznawanych za pierwszorzędne dokonania poezji Kiplinga lub sztandarowe manifestacje jego przekonań nie doczekało się spolszczonych wersji, które czytelnicy zaakceptowaliby jako tłumaczenia kanoniczne i uznali - jak ujmuje to Juliusz Zuławski - za trwale osadzony „we własnym piśmiennictwie obcy utwór”.

Zapewne trudno wskazać bardziej symptomatyczny przykład niż wiersz The White Man's Burden. Słynny i dziś, nie tylko za sprawą rozlicznych, sprowokowanych kontrowersyjną treścią, literackich polemik, nawiązań czy parodii, ale przede wszystkim przypominany przez niemal każdą z istotniejszych prac luminarzy teorii postkolonialnej. Edward Said pisze wszak o „wyjątkowej sile, z jaką Kipling dodawał do języka nowe pojęcia i wyrażenia”, wśród nich przede wszystkim „Brzemię Białego Człowieka”" . Homi Bhabha omawia „normatywne ideologie postępu określane jako »misja cywilizacyjna $\ll$ czy $\gg$ brzemię białego człowieka "”. Leela Gandhi zaś o sytuacji europejskich kobiet w rzeczywistości kolonialnej powiada, że „akceptowały swój udział w brzemieniu białych ludzi" . Ilekroć jednak tłumacze stoją przed koniecznością oddania w języku polskim partii utworu - większej niż tylko powszechnie rozpoznawalny tytuł - każdorazowo niemal dokonują przekładu samodzielnie. Na przykład, w tłumaczeniu Wysp Normana Daviesa z 2012 roku, który powołuje się na różne liryki Kiplinga kilkukrotnie, Elżbieta Tabakowska z reguły sięga po dostępne warianty spolszczeń Macieja Słomczyńskiego i Stanisława Helsztyńskiego.

${ }^{6} \mathrm{~J}$. Żuławski, O tłumaczeniu ksiag, [w:] Przekład artystyczny, red. S. Pollak, t. 2, Ossolineum, Wrocław 1975, s. 382.

7 E. Said, Kultura i imperializm, tłum. M. Wyrwas-Wiśniewska, Wydawnictwo Uniwersytetu Jagiellońskiego, Kraków 2009, s. 162.

${ }^{8} \mathrm{H}$. Bhabha, Miejsca kultury, tłum. T. Dobrogoszcz, Wydawnictwo Uniwersytetu Jagiellońskiego, Kraków 2010, s. 77.

9 L. Gandhi, Teoria postkolonialna. Wprowadzenie krytyczne, tłum. J. Serwański, Wydawnictwo Poznańskie, Poznań 2008, s. 87. 
Przywołane przez historyka strofy The White Man's Burden (pierwszą $\mathrm{i}$ trzecią) proponuje jednak czytelnikom we własnej wersji ${ }^{10}$ :

Podnieście brzemię białego człowieka -

Wyślijcie kwiat swojego plemienia Nuże, popędźcie synów na wygnanie,

By jeńców waszych spełniali marzenia.

Niechaj tym ludom spłoszonym i dzikim

Służą, swym jarzmem do ziemi przygięci,

Tym, co pojmani dopiero, niechętni,

Co na wpół diabłem są, na wpół dziecięciem.

Podnieście brzemię białego człowieka -

Okrutne wojny o pokój wzniecajcie -

Głodu łakome napełnijcie usta, Chorobom hasło do odwrotu dajcie,

A gdy już kres tej drogi będzie bliski,

Im wytyczony cel wam zajaśnieje, Patrzcie, jak szał pogański i lenistwo

Do szczętu wasze niweczy nadzieje.
Take up the White man's burden -

Send forth the best ye breed Go bind your sons to exile

To serve your captives' need;

To wait in heavy harness

On fluttered folk and wild

Your new-caught, sullen peoples,

Half devil and half child.

Take up the White Man's burden The savage wars of peace -

Fill full the mouth of famine And bid the sickness cease;

And when your goal is nearest

The end for others sought, Watch Sloth and heathen Folly

Bring all your hope to nought.

10 N. Davies, Wyspy, tłum. E. Tabakowska, Znak, Kraków 2012, s. 745746. Wszystkie oryginały, jeśli nie zaznaczono inaczej, cytowane za stroną internetową Complete Collection of Poems by Rudyard Kipling (www.poetryloverspage.com/poets/kipling; dostęp: 20.04.2017). 
Czytelnik polski zainteresowany pozostałymi ustępami tekstu Kiplinga znajduje, na przykład, strofę drugą w innej publikacji - tym razem ekonomiczno-socjologicznej - Williama Easterly'ego w przekładzie Elżbiety Łyszkowskiej ${ }^{11}$ :

Weź brzemię białego człowieka Wytrwaj w nim cierpliwie, By ukryć groźbę terroru I sprawdzić pokaz dumy; Prostą i otwartą mową, Po raz setny szczerą, By szukać czyjegoś zysku I wypracować czyjąś korzyść.
Take up the White Man's burden In patience to abide, To veil the threat of terror And check the show of pride; By open speech and simple, An hundred times mad plain. To seek another's profit, And work another's gain.

Beata Wilga zaś, w tłumaczeniu historiozoficznej monografii Nialla Fergusona, przytacza polską wersję czterech linii strofy piątej ${ }^{12}$ :

Dźwignij brzemię Białego Człowieka -

I odbierz jego starą nagrodę:

Potępienie tych, od których jesteś lepszy

Nienawiść tych, których strzeżesz. The hate of those ye guard -
Take up the White man's burden And reap his old reward:

The blame of those ye better,

Fragmenty te jednakże, wespół z innymi, mniej lub bardziej rozbudowanymi wersjami utworu dostępnymi w języku polskim, służą tylko za ilustracje w wywodach argumentacyjnych. Są nie tyle próbą przybliżenia liryki Kiplinga szerszej publiczności czytelników poezji, co raczej „efektem ubocznym” tłumaczeń rozpraw przeznaczonych

${ }^{11}$ W. Easterly, Brzemię białego człowieka, tłum. E. Łyszkowska, Wydawnictwo Naukowe PWN, Warszawa 2008, s. 9.

${ }^{12}$ N. Ferguson, Imperium. Jak Wielka Brytania zbudowała nowoczesny świat, tłum. B. Wilga, Wydawnictwo Literackie, Warszawa 2007, s. 340. Strofa pierwsza wiersza Kiplinga, również przywołana w rozprawie, ma w tłumaczeniu Beaty Wilgi postać: „Dźwignij brzemię Białego Człowieka / wyślij najlepszych ze swej rasy / skaż swych synów na wygnanie / aby służyli na trudnym posterunku / ludom niespokojnym, dzikim, posępnym /diabłom i dzieciom na poły". 
dla odbiorców publikacji naukowych i popularnonaukowych. W dziejach polskiej recepcji The White Man's Burden jest to nowość choćby dlatego, że przez długi czas tekst ten funkcjonował według młodopolskiego jeszcze paradygmatu, zgodnie z którym oceniając twórczość Kiplinga, nie można odmawiać „oryginalności jego balladom i pieśniom, ale ideologia ich każe polskim krytykom ostro je potępić". Wskutek powtarzalności utrzymanych w podobnym tonie osądów, o „głośnym wierszu urzędowego wieszcza dżingoizmu [...] wiedziano tylko z relacji”'13. Przypadek Brzemienia Białego Człowieka był dla obecności poezji Kiplinga w literaturze polskiej przez długi czas szczególnie znamienny, ale bynajmniej nie jedyny. Przykłady tego typu można z łatwością mnożyć. Passusy z wierszy, wyrwane z kontekstu całości utworu, a tym samym często odbiegające od wykładni interpretacyjnej pełnych oryginałów, oferują czytelnikom obraz literackiej sylwetki poety $w$ najlepszym razie niekompletny i zniekształcony, tym skwapliwiej więc uzupełniany obiegowymi opiniami krytycznymi.

Osobliwości funkcjonowania w przestrzeni literacko-kulturowej polskich przekładów, a wraz z nimi czytelniczej recepcji poezji Kiplinga, są rezultatem nie tylko rozrzucenia utworów na łamach różnych publikacji oraz częstego drukowania ich we fragmentach. Czynnikiem, który od okresu modernistycznego do najnowszych przekładów $\mathrm{z}$ drugiej dekady XXI wieku, warunkuje kształt tłumaczeń, jest ich nieustanne uwikłanie w dominujące akurat w Polsce dyskursy kulturowe, społeczne i polityczne. Świadczy to niewątpliwie o ponadczasowości utworów, lecz również konsekwentnie - na każdym etapie historycznym minionego i bieżącego wieku - rodzi pośród publikowanych spolszczeń grupę takich, których silna relacja z owymi dyskursami jest wynikiem nie tylko dalekowzroczności refleksji pisarza i uniwersalizmu jego prac, ale także ingerencji tłumaczy w komunikaty. Przedmiotem naszej uwagi jest właśnie historia i rodzaje tych translatorskich ingerencji oraz kontekstowych uwikłań, prześledzonych w szkicowej retrospekcji.

13 W. Krajewska, Recepcja literatury angielskiej $w$ Polsce $w$ okresie modernizmu, Ossolineum, Wrocław 1972, s. 124. 
„Zadziwiające jest” - pisze Wanda Krajewska - „jak mało zainteresowała się Młoda Polska wierszami Kiplinga”. Wprawdzie „zdobył licznych czytelników u nas prawie w tym samym czasie, co w Anglii”, ale „z jedną ważną różnicą: gdy tam zarówno jego melodyjne, prostym językiem pisane wiersze, jak i opowiadania miały masowy odbiór, w Polsce był niemal wyłącznie autorem nowel i powieści"14. Sporadyczne przekłady wierszy bynajmniej nie najbardziej rozpoznawalnych ${ }^{15}$, spotykały się z nikłym zainteresowaniem, głównie ze względu na tematykę odległą od ówczesnych oczekiwań czytelniczych: „Kipling był dla wiktorianów odkrywcą Indii w literaturze i sympatykiem prostego żołnierza $\mathrm{w}$ dominiach. U nas, gdzie problematyka ta nie znajdowała odzewu, stał się przede wszystkim autorem opowieści o zwierzętach"16. Takie uwarunkowania recepcji nie pozostawały bez wpływu na sposoby przekładania jego tekstów. Tendencja do dostrzegania w prozie Brytyjczyka narracji quasi-bajkowych, kierowanych głównie do dzieci, rodziła częste uproszczenia i eksplikacje treści, w rodzaju tych, jakie napotykał czytelnik opowiadania z Księgi ḋ̇ungli, które w zwięzłym angielskim tytule wymienia jedynie onomatopeiczne imię głównego (zwierzęcego) bohatera: Rikki-Tikki-Tavi. Polskie anonimowe tłumaczenie z 1904 roku zastępuje krótki tytuł całą streszczającą fabułę frazą: $O$ tem, jak dzielny Rikitiki pokonat

14 Ibidem, s. 124, 149. Entuzjastyczne recenzje krytyków, w rodzaju opinii Brunona Jasieńskiego o Kiplingu - „jako powieściopisarz dobry, jako nowelista znakomity, jako poeta - największy wieszcz anglo-amerykański” (ibidem, s. 152) - również należały do rzadkości.

15 „Trochę przekładów utworów poetyckich pojawiło się dopiero w XX w. T. Prażmowska ogłosiła w $1908 \mathrm{r}$. w $\gg$ Bluszczu « kilka wierszy z cyklu The Seven Seas, w 1913 r. w »Słowie Polskim« ukazała się Oda do Francji (France) w przekładzie prawdopodobnie J. Bandrowskiego, Nawrocki przetłumaczył w »Sowizdrzale « Starego wachmistrza (Shillin'a Day), a Miriam $\mathrm{w} \gg Z$ Zdroju $\ll$ Pałac (The Palace). Nie wszedł Kipling do antologii poetów angielskich - ani Kasprowiczowskiej, ani Langego - co świadczyłoby, że nie zainteresował modernistów mimo słabych i zresztą spóźnionych prób Miriama i Nawrockiego wprowadzenia go na łamy pism awangardowych" (W. Krajewska, Recepcja literatury..., s. 124).

16 Ibidem, s. 208. 
strasznego węża okularnika ${ }^{17}$. Nieliczne zaś wiersze spolszczone przez tłumaczy doby modernizmu - w tym tak rozpoznawalnych jak Zenon Przesmycki czy Jan Kasprowicz - wyraźnie charakteryzuje styl właściwy rodzimej poezji młodopolskiej. Trudno o bardziej wymowny przykład niż Kasprowiczowy ${ }^{18}$ wariant The City of Sleep, którego już inicjalna strofa przyjmuje formę:

Na krańcu czerwonych tych wód, Gdzie lampa samotna się pali,

Czy wiecie, gdzie Litość ma gród

Wzniesiony wśród cichej snu fali? Tam ból swój składają nędzarze,

Człek chory tam czuje się zdrów Nam zasię, o Boże! o Boże!

Nim oko przymrużyć się może Opuszczać Policjant-Dzień każe

Ten cichy, ten błogi Gród snów.
Over the edge of the purple down, Where the single lamplight gleams,

Know ye the road to the Merciful Town

That is hard by the Sea of Dreams Where the poor may lay their wrongs away,

And the sick may forget to weep?

But we - pity us! Oh, pity us!

We wakeful; ah, pity us! -

We must go back with Policeman

Day -

Back from the City of Sleep!

17 Patrz: J. Gronau, Wędrówki po bibliografii angielskiego autora Rudyarda Kiplinga, Kraków 2007, s. 148. Późniejsza, autoryzowana wersja Józefa Birkenmajera nosi już identyczny z oryginalnym tytuł Rikki-Tikki-Tavi (R. Kipling, Księga dżungli, tłum. J. Birkenmajer, Nasza Księgarnia, Warszawa 1971, s. 113).

${ }^{18}$ R. Kipling, Pod niebem indyjskim. Wybór noweli, tłum. A. Gawrońska, Księgarnia H. Altenberga, Lwów 1905, s. 214-215. Jak wspomina w emigracyjnym periodyku Zofia Kozarynowa: „w pierwszym dziesięcioleciu b. wieku firma Altenberg i Ska we Lwowie wydała tom nowel Kiplinga w przekładzie Antoniny Gawrońskiej. Jedna z tych nowel, Chłopiec znad morza (The Brushwood Boy), zawierała przytoczony tu wiersz. Nie czując się na siłach oddania go z należytą poetycznością, tłumaczka zwróciła się do zaprzyjaźnionego Jana Kasprowicza z prośbą o pomoc. Chętnie podjął się zadania, zastrzegając sobie nie ujawnianie jego nazwiska. Mimo to tłumaczka podała je w odsyłaczu” (Z. Kozarynowa [ps. Rębajło], Nieznany Kipling, nieznany Kasprowicz, „Dziennik Polski i Dziennik Żołnierza” 1984, nr 46, s. 3). 
Jak ocenia Zofia Kozarynowa: „Kasprowicz wykazuje w tych strofach miękkość formy, rzadko u niego spotykaną. Jedyna usterka to zrozumienie przez niego $\gg$ purple $\ll$ jako $\gg$ czerwony $\ll$, nie zaś »fioletowy«, właściwie przez Kiplinga odczuty kolor fal morskich w nocy”" . Można jednak przypuszczać, że odnotowana „usterka” nie jest banalną pomyłką językową, lecz elementem domestykacyjnej strategii przekładowej. Oddanie frazy "the edge of the purple down” jako „kraniec czerwonych tych wód”, przywodzi wszak na myśl obrazowanie właściwe dla poezji autorskiej tłumacza: znany choćby z Dies Irae wers „a krew w tych morzach, w tych czerwonych rzekach”, sformułowanie z IX części cyklu $W$ ciemności schodzi moja dusza („nad brzegi idziesz spochmurniałych wód”) czy pejzaż z liryku U piramidy Cestjusza: „wody czerwone, gdy nad niemi włada / majestat zorzy"20. Podobnie inne cechy typowe dla poezji młodopolskiej wprowadza Kasprowicz arbitralnie w procesie transferu. Intensyfikuje oniryzm (sugerowany w oryginale określeniem „the Sea of Dreams”) wraz ze zmianą angielskiego miejsca lirycznej akcji z „the city of sleep” na „cichy, błogi gród snów” (czyli: gród marzeń sennych zamiast po prostu miasta, którego mieszkańcy śpią) oraz nastrój weltschmerzu i spleenu („the poor may lay their wrongs away” jako „ból swój składają nędzarze”). Stosuje również wtręty gwarowo-folklorystyczne („zasię” w roli odpowiednika dla „but”) czy właściwe własnym hymnom, pełne patosu i rozpaczy apostrofy do Boga („o Boże! o Boże!” jako ekwiwalent znacznie mniej eksplicytnie religijnego zwrotu „pity us! Oh, pity us!”).

Wykonany przez Kasprowicza przekład włącza spolszczony wiersz Kiplinga w młodopolski dyskurs literacki: zakresem tematycznym i wprowadzonymi modyfikacjami leksykalno-stylistycznymi upodabnia go do poczytnej na przełomie wieków liryki rodzimej. Czyni to zresztą podług neoromantycznych pryncypiów translatorskich - opartych na postulacie Friedricha Schillera, „by w dziele tłumacza

19 Z. Kozarynowa, Nieznany Kipling..., s. 3.

${ }^{20}$ J. Kasprowicz, Dzieła, red. S. Kołaczkowski, Kraków 1930. Odpowiednio tomy: IX (Ginącemu światu), s. 66; VII (Krzak dzikiej róży), s. 18; I (Pierwsze poezje), s. 170. 
żył geniusz języka, na który je tłumaczono, a nie języka oryginału”21 - zyskując swojej pracy przychylność krytyków. Jak bowiem pisał o technikach przekładowych poety Adolf Nowaczyński: „nie są to tłomaczenia poetów angielskich, to są w całej tego słowa wadze przyswojenia poezji polskiej poesy angielskiej, to są natchnione a dosadne transpozycje twórcze na ton, tok i takt polskiej mowy, to są niekiedy wżycia się momentalne w obce typy twórcze [...] zjednoliczone i ujednobarwione indywidualnym językiem Kasprowiczowym”22.

W odróżnieniu od modernistycznych, literackie trendy międzywojenne przyniosły szczególną popularność tłumaczeniom tych wierszy Kiplinga, które w nieskrywany sposób traktowały o relacji jednostki wobec ojczyzny, służbie narodowi i państwu, nierzadko w formach religijnych o tonacji modlitewnej. Niepodległość II Rzeczypospolitej sprzyja także „rozwijającej się pomiędzy rodakami naszymi idei kolonizacyjnej" ${ }^{23}$. Dlatego też poezja noblisty nie tylko nie spotyka się z niechęcią odbiorców, ale jej upowszechnianie oznacza w recepcji czytelników niemal deklarację polityczną i światopoglądową - jak wspomina Czesław Miłosz: wówczas „angielski oznaczał opcję prozachodnią" ${ }^{24}$. Co więcej, publikowane przekłady wierszy Kiplinga promowały wartości patriotyczne i obywatelskie, w ujęciu Stanisława Helsztyńskiego: „tytaniczne”, „tyrtejskie”25,

${ }^{21}$ Cyt. za: Pisarze polscy o sztuce przekładu 1440-2005. Antologia, red. E. Balcerzan, E. Rajewska, Wydawnictwo Poznańskie, Poznań 2007, s. 99.

22 A. Nowaczyński, Angielskie przekłady Jana Kasprowicza, [w:] idem, Szkice literackie, Poznań 1918, s. 157-158.

23 Anonim, cyt. za: P. Fiktus, „Nowa Polska” w polskiej myśli kolonialnej do 1939, [w:] Prace z myśli polityczno-prawnej oraz prawa publicznego, red. M. Sadowski, P. Szymaniec, Wydział Prawa, Administracji i Ekonomii Uniwersytetu Wrocławskiego, Wrocław 2012, s. 109. Patrz także: M.A. Kowalski, Kolonie Rzeczypospolitej, Bellona, Warszawa 2005.

${ }^{24}$ C. Miłosz, Przypis po latach, [w:] idem, Kontynenty, Znak, Kraków 1999, s. 6.

25 „Tytanizm Kiplinga, Newbolta, Henleya, znalazł ujście w imperjaliźmie, który pod koniec stulecia, kierowanego zaborczą dłonią polityków, wezbrał wysoko także w poezji i wydał szereg gromko grzmiących manifestów. Nie ostatnie miejsce śród Hymnów skruchy i ballad o Drake’u, zajmują 
pożądane zatem w odbudowywanej i scalanej po okresie zaborów Polsce. Modyfikacje wprowadzane przez tłumaczy do niektórych tekstów podkreślały dodatkowo uniwersalizm lirycznych komunikatów - także przez familiaryzację, redukcję w treści elementów odsyłających nazbyt jednoznacznie do odległych od Wisły realiów Wspólnoty Brytyjskiej.

Jako reprezentacyjny przykład przywołać można jubileuszowy Hymn skruchy (Recessional), spolszczony przez Helsztyńskiego ${ }^{26} \mathrm{w}$ roku 1929. Utwór, w formie podziękowania kierowanego do Boga, wyraża dumę z państwowych sukcesów. W postaci prośby do Stwórcy natomiast - przestrogę przed podzieleniem losu innych imperiów, w których pycha obywateli poprzedziła upadek:
Jeśli upojeni blaskiem mocy rozpuścimy bluźniercze języki chwalbą, jak poganie w mrokach nocy albo mniejszych plemion naród dziki bądź, bądź przy nas, o zastępów Boże.

Już samo memento ujęte w tekście Kiplinga odbiorca w dwudziestoleciu międzywojennym z łatwością mógł odnieść do sytuacji polskiej - odzyskania suwerenności ojczyzny i jej, przynajmniej propagandowo głoszonych, powodzeń gospodarczo-militarnych. Helsztyński jednak dodatkowo wzmacnia to czytelnicze wrażenie zmianami oryginalnego komunikatu. Podczas gdy pierwowzór wyraźnie traktuje o Dominium Brytyjskim („we hold / Dominion over palm and pine”), przekład pomija nazwę właściwą tej formie ustrojowej wraz z zastosowaniem ogólnikowej formuły: „gdzie palm piaski i gdzie sosen rzeka / władzę twoja nam zleciła wola”. Oryginalne nawiązanie do pamięci o historii tryumfów Royal Navy w oceanicznych bataliach, obecne dzięki przywołanym postaciom „kapitanów” marynarki („the Captains and the Kings depart”), tłumaczenie zastępuje frazą pozbawioną aluzji do - znikomej wszak w dziejach

rymy naprawdę tyrteuszowskie" (S. Helsztyński, Liryka angielska XX wieku, Warszawa 1929, s. 6).

26 Ibidem, s. 158. 
Polski - tradycji marynistycznej: „władcy, wojownicy mrą i giną”. Nawet kiedy Kipling opisuje plener batalistyczny wersem „on dune and headland sinks the fire”, Helsztyński zastępuje oryginalne „wydmy” i „cyple” polskimi - tak językowo, jak geograficznie - „żuławami”: „na żuławach, lądach popiół siwy”.

W połowie drugiej dekady okresu międzywojennego poczytnością cieszą się, często kilkukrotnie przedrukowane, przekłady wykonane przez Józefa Czechowicza. Kunsztowne poetycko, korespondują z napiętą sytuacją polityczną polsko-niemiecką i niepokojącymi doniesieniami prasowymi. Czechowicz wybiera bowiem utwory o charakterze pieśni patriotyczno-militarnych. Nieliczne i subtelne substytucje, jakie stosuje w lirycznych komunikatach, służą ich ujednoznacznieniu oraz, poprzez wprowadzenie słów-kluczy w wyeksponowanych partiach tekstu, podkreśleniu relacji z lokalnym kontekstem historycznym - mobilizacji przed spodziewanym wybuchem II wojny światowej. Szczególnie wyraźnie ukazuje to sam sposób tłumaczenia tytułów, a zatem tej części tekstu, która - jak podkreśla Jerzy Jarniewicz - „zapowiada temat dzieła”, wywołuje u czytelnika „określony nastrój, wzbudza oczekiwania”, a zachęcając do lektury, pełni istotną „funkcję komercyjną" ${ }^{27}$. W roku 1934 publikuje Czechowicz w sanacyjnym tygodniku "Pion” polski wariant The Song of the Sons. Utwór w obu wersjach językowych nawołuje do zjednoczenia rozproszonych po świecie rodaków („we that were bred overseas wait and would speak with our kin”), ofiarnej służby narodowi oraz miłości obywateli do ojczyzny ("gifts have we only to-day / love without promise or fee”) - przy czym samo aktywizujące polskiego czytelnika przedwojennego słowo-klucz „ojczyzna” napotkać można jedynie w tłumaczeniu. Kipling zamiast niego posługuje się symbolem „Matki” („Mother, be proud of thy seed!”), do której synowie (domyślnie: obywatele) kierują deklarację lojalności. Czechowicz zaś już tytuł rozszerza o wyraźne dookreślenie, iż chodzi oczywiście o Pieśn

27 J. Jarniewicz, Tytuł w przekładzie, [w: Pisarze polscy o sztuce przekładu 1440-2005. Antologia, red. E. Balcerzan, E. Rajewska, Wydawnictwo Poznańskie, Poznań 2007, s. 411, 413. 
synów ojczyzny ${ }^{28}$. Podobnie drukowany w 1935 roku przekład modlitewnego hymnu, ze znamiennie profetyczną puentą

gniew pułki już pozbierał zbliża się krwawy czas. Jakeś praojców wspierał wesprzyj dziś, Panie, nas.
E'en now their vanguard gathers, e'en now we face the fray as Thou didst help our fathers, help Thou our host to-day.

tłumacz przedstawia czytelnikom polskim z drobną acz symptomatyczną modyfikacją w tytule. Frazę Hymn Before Action oddaje bowiem jako Hymn przed wojną ${ }^{29}$, podczas gdy hasło „wojna” lub jego angielskie synonimy explicite w oryginale nie występują wcale. $\mathrm{Z}$ podobnym typem translatorskiej ingerencji w tekst mamy do czynienia w patriotycznej pieśni The Return, spolszczonej przez Czechowicza z niedwuznacznie militarnym akcentem w tytule, jako Powrót wojsk ${ }^{30}$.

Okres powojenny i PRL-owski jest dla twórczości poetyckiej Kiplinga czasem ostracyzmu. „Do 1956 roku” - odnotowuje Bogomilska - „nie wznawiano dzieł tego autora” ${ }^{31}$, nieprecyzyjne zaś lub błędne informacje na temat jego prac nie należały do rzadkości ${ }^{32}$.

${ }^{28}$ Cyt. za: J. Czechowicz, Przekłady, red. W. Kruszewski, D. Pachocki, Wydawnictwo Uniwersytetu Marii Curie-Skłodowskiej, Lublin 2011, s. 29 (pierwodruk wiersza miał miejsce w periodyku „Pion” 1934, nr 32).

${ }^{29}$ Ibidem, s. 27-28 (przekład wznowił Czechowicz w wysokonakładowym czasopiśmie „Państwo Pracy” 1935, nr 13, ogłosił zaś wcześniej w periodyku „Pion” 1933, nr 7).

30 Ibidem, s. 30-32 (pierwodruk: „Pion” 1934, nr 1).

${ }^{31}$ K. Bogomilska, Rudyard Kipling..., s. 16.

32 Na przykład: w przedmowie Mikołaja Kozakiewicza do powieści Stalky i spótka (tłum. J. Birkenmajer, Czytelnik, Warszawa 1978, s. 11) znajduje czytelnik informację o dwóch wierszach Kiplinga wymienionych jako przykłady powieści: „Kipling mniej interesuje się psychologią żołnierzy, a więcej uwagi poświęca ich heroicznym wyczynom w niezliczonych »małych wojnach « imperialnych, jak też owej dziwnej sympatii czy wręcz miłości tych ludzi dla tajemniczego i pełnego orientalnej egzotyki Wschodu, deptanego ich ciężkimi żołnierskimi butami. [...] Takie powieści jak Gunga Din czy Mandalay są typowymi dziełami dla tego okresu”. 
Na kontrolowanym przez socjalistyczne państwo oficjalnym rynku publikacji ${ }^{33}$ ten wydawniczy bojkot uzasadniały jego krytyczne poglądy wobec ekspansji rosyjskiej ${ }^{34}$ oraz renoma gloryfikatora brytyjskiego imperializmu, a więc idei stojącej w sprzeczności z obowiązującą w bloku wschodnim doktryną polityczną, która imperializm zachodni ocenia jako „najwyższe stadium kapitalizmu”35. Tę daleko posuniętą niechęć do przypominania czytelnikom prac poety dobrze ilustruje przykład kilkutomowej monografii Dzieje literatur europejskich z 1982 roku. Obszerny rozdział dotyczący literatury angielskiej poświęca mu jeden siedmiozdaniowy akapit. Przedstawia Kiplinga, bez informacji o jego statusie noblisty, jako wprawdzie „utalentowanego”, ale „omamionego wykoncypowaną przez siebie misją białego człowieka” rzecznika „minionej i wysoce wątpliwej chwały imperium brytyjskiego" ${ }^{36}$. Rzadkie wyjątki od tego sposobu prezentowania pisarza stanowią szkice Witolda Chwalewika z lat 60., w których badacz niejednokrotnie wyraża przekonanie, iż obiegowe „sądy wczorajsze o Kiplingu albo są niewystarczające, albo

33 Jak wspomina Julian Kornhauser, „polityka miała decydujący wpływ na wybór autorów do tłumaczenia i ich konkretnych wierszy, które musiały być reprezentatywne dla określonego nurtu literackiego. Także na dobór tłumaczy i redaktorów (tj. autorów opracowania) oraz niejednokrotnie samych wydawnictw, mających placet na prowadzenie serii, kolekcji czy bibliotek" (Polityka i przekład. O dwóch antologiach liryki niemieckiej, [w:] Poezja polska i niemiecka $w$ przekładach współczesnych, red. U. Jekutsch, A. Sulikowski, PPH Zapol Dmochowski, Sobczyk, Szczecin 2002, s. 243).

34 Wyrażone między innymi w opowiadaniu The Man Who Was z 1907 roku.

35 W. Lenin, Imperializm jako najwyższe stadium kapitalizmu, tłum. J. Górski, Książka i Wiedza, Warszawa 1980 (szkic opublikowany po raz pierwszy w 1917 roku). Opisywane przez Kiplinga heroiczne batalie kolonialne Włodzimierz Lenin określa mianem „zaborczych, grabieżczych i zbójeckich wojen imperialnych”, które „są absolutnie nieuniknione dopóki istnieje własność prywatna" (s. 4, 5).

${ }^{36}$ H. Zbierski, Literatura angielska, [w:] Dzieje literatur europejskich, red. W. Floryan, t. 2, Państwowe Wydawnictwo Naukowe, Warszawa 1982, s. 527. 
fałszywe" 37 oraz studium Romana Dyboskiego z 1957 roku, gdzie literaturoznawca krótki przegląd najbardziej znanych wierszy Kiplinga wieńczy konstatacją: „oto zaiste kodeks postępowania osobistego, któremu trzeba przyznać więcej niż przemijającą wartość doktryny jednej historycznej epoki; oto wyraz nagromadzonego doświadczenia i skupionej siły moralnej wielkiego narodu, od którego warto się uczyć" 38 .

W tym okresie, prócz pojedynczych, okazjonalnie przekładanych wierszy $^{39}$, próbę popularyzatorskiego spolszczenia istotniejszych tekstów lirycznych Kiplinga stanowi jedynie trzytomowa antologia Poeci języka angielskiego ${ }^{40}$. Poza przedrukiem wcześniejszych tłumaczeń Czechowicza i Helsztyńskiego, czytelnik odnajduje w niej tak cenione przez krytykę anglosaską utwory jak ballada Danny Deever (przez Thomasa Stearnsa Eliota określona mianem „niepospolitej”"11) w wariancie

37 „Kipling-artysta nie był w rzeczywistości ani dziennikarzem, ani propagandystą politycznym. Czas, sprawdzając dzieło, coraz bardziej wyraźniej ukazuje autora takim, jakim naprawdę był - przyjacielem całego świata" (W. Chwalewik, Rudyard Kipling w świecie dzisiejszym, [w:] Europejskie związki literatury polskiej, red. J. Jakubowski, Państwowe Wydawnictwo Naukowe, Warszawa 1969, s. 479, 483).

38 R. Dyboski, Sto lat literatury angielskiej, Instytut Wydawniczy Pax, Warszawa 1957, s. 659.

39 Jak na przykład Zew (The Recall) przełożony jako jedyny wiersz Kiplinga w Antologii liryki angielskiej 1300-1950 Jerzego Pietrkiewicza (Instytut Wydawniczy Pax, Warszawa 1957), The Sons of Martha (Synowie Marty), The Puzzler (Celt i Anglik) czy The Wrath of the Awakened Saxon w przekładzie Włodzimierza Lewika, ujęte w tomie szkiców literaturoznawczych André Mauroisa (Magicy i logicy. Szkice o pisarzach angielskich, Czytelnik, Warszawa 1959) tudzież dwa wiersze $z$ The Jungle Book włączone do antologii Roberta Stillera Strofy o zwierzętach (Iskry, Warszawa 1982) i wiersz Hyaenas (Hieny) uwzględniony w jego Strofach $z$ dreszczykiem (Iskry, Warszawa 1986).

40 Poeci języka angielskiego, red. H. Krzeczkowski et al., t. 3, Państwowy Instytut Wydawniczy, Warszawa 1974, s. 58-68.

${ }^{41}$ T.S. Eliot, Szkice literackie, tłum. W. Chwalewik i in., Instytut Wydawniczy Pax, Warszawa 1963, s. 151. 
Andrzeja Nowickiego, czy choćby pieśń Mandalay i wiersz Tommy w wersjach Macieja Słomczyńskiego. Pod względem zastosowanych technik translatorskich większość z tych przekładów - przeciwnie do tłumaczeń młodopolskich i międzywojennych - cechuje wyraźna egzotyzacja. Ich czytelnik odnosi wrażenie, że będąca przedmiotem opisu problematyka dotyczy niemal wyłącznie realiów Commonwealthu. I choć w przypadku nostalgicznej pieśni wyrażającej tęsknotę żołnierza za służbą w koloniach jest to wrażenie u czytelnika polskiego oczywiste (głównie wskutek nagromadzenia licznych nazw własnych typu Mandalay, Rangun, Tihibei, Suez, Chiny, Chelsea), to w przekładzie, na przykład, liryku koszarowego Tommy jest już w znacznym stopniu efektem serii decyzji tłumacza.

Treść utworu jest bowiem nader uniwersalna: traktuje o pogardliwym stosunku społeczeństwa do żołnierzy w czasach pokoju, a pozornie entuzjastycznym ich uprzywilejowaniu w sytuacji zagrożenia konfliktem. Uniwersalizm zresztą sugeruje Kipling samym wyborem imienia tytułowego bohatera. Zdrobnienie imienia Thomas jest w potocznej angielszczyźnie określeniem zawodowego żołnierza niskiej rangi ${ }^{42}$ - tłumacz zaś w tekście zastępuje je polskim odpowiednikiem, wprawdzie słownikowo ekwiwalentnym, ale bez jakichkolwiek konotacji militarnych: „Tomek”. Inne obco brzmiące frazy i określenia Słomczyński albo pozostawia w angielskich formach (np. „music-hall”), albo też oddaje za pomocą wyrażeń niezrozumiałych bez znajomości kulturowego kontekstu oryginału. Barman wyrzucający szeregowca z lokalu używa zwrotu: „we serve no red-coats here”, w którym określenie „red-coat” jest aluzją do koloru munduru w brytyjskiej piechocie, a w slangu wojskowym wykorzystywanym przez Kiplinga denotuje po prostu „żołnierza”. Wersja tłumacza wymaga od czytelnika znajomości tego kontekstu, ponieważ kwestia barmana brzmi w niej: „czerwonym bluzom tu piwa się nie podaje”.

${ }^{42}$ Imię i nazwisko "Thomas Atkins” było stosowane w formularzach wojskowych jako przykład instruujący prawidłowe ich wypełnianie; zdrobnienie „Tommy”, zakorzenione w potocznej angielszczyźnie, znalazło później liczne użycia językowe - na przykład karabin maszynowy stosowany przez szeregowych żołnierzy określany jest często jako „tommy gun”. 
Z kolei frazę z repliki obrażonego szeregowca, „the widow's uniform is not the soldier-man's disgrace”, Słomczyński przekłada jako: „nosić mundur wdowy to nie jest do hańby powód"43 - pozostawiając bez jakiejkolwiek eksplikacji enigmatyczny „mundur wdowy” (określenie odnoszące się do statystycznego żołnierza w służbie „Wdowy z Windsoru”, królowej Wiktorii). Przykłady tego typu można mnożyć. Efekt jaki wspólnie tworzą, to czytelnicze wrażenie obcości świata przedstawionego w tekście; podobnie jak egzotyczne realia imperialne, tak i rozpowszechniona w społeczeństwie pogarda cywilów wobec służb mundurowych nie wydaje się problemem pozabrytyjskim, w tym także - obecnym w Polskiej Rzeczpospolitej Ludowej.

Wśród zachodnich poetów odzyskujących właściwą im rangę w polskiej literaturze przekładowej po 1989 roku Rudyarda Kiplinga długo nie było. Choć literaturoznawstwo postkolonialne stopniowo zaczęło odchodzić od stereotypowej lektury tekstów autora na rzecz odkrywania w nim „prekursora teorii melting pot community” i „zmieniania obrazu jego pisarstwa wytworzonego przez wcześniejszych badaczy imperialnego dyskursu"44, to propozycje nowych odczytań nie przełożyły się jeszcze w latach 90. na niebłahe zwiększenie liczby dostępnych przekładów ${ }^{45}$. Dopiero połowa pierwszej dekady XXI wieku przynosi znaczniejsze nowości translatorskie. Z jednej strony, przekłady realizowane konsekwentnie w ramach strategicznych projektów stricte literackich, ukierunkowanych na popularyzację Kiplinga w Polsce. Z drugiej zaś - tłumaczenia pragmatycznie włączone w lokalną publicystykę społeczno-polityczną. Chociaż oba te „nurty” próbują ukazać uniwersalność problematyki poezji noblisty i jej aktualność

43 Patrz: Poeci języka angielskiego, red. H. Krzeczkowski i in., t. 3, Państwowy Instytut Wydawniczy, Warszawa 1974, s. 59-61.

${ }^{44}$ M. Zaleski, Kipling i Conrad..., s. 83.

${ }^{45}$ Liryka Kiplinga jest oczywiście obecna w antologiach prac poetów-noblistów, jednakże w wersjach znanych już z poprzednich okresów przyswajania przez tłumaczy jego twórczości polszczyźnie (patrz m.in.: Poeci nobliści 1901-1993, red. K. Waśkiewicz, Anagram, Warszawa 1994; Laurowo i jasno: antologia wierszy laureatów literackiej Nagrody Nobla, red. L. Żuliński, Wydawnictwo Bohdana Wrocławskiego, Warszawa 1994). 
w ważkich dyskursach współczesności, to tym, co je wyraźnie różni, jest zakres ingerencji tłumaczy w komunikaty źródłowe, a tym samym stopień sprzężenia z kontekstem kulturowym, w jaki są wprost lub jedynie implicytnie włączane.

W ostatnim dziesięcioleciu sytuacja polskich czytelników poezji Brytyjczyka, jak niebezpodstawnie deklaruje Kazimierz Rafalski w liście do Kipling Society „is going to change slightly for the better”46. Opinię tłumacza uzasadnia praktyka miesięcznika literackiego „Akant”, który od 2005 roku publikuje spolszczenia takich wierszy, jak między innymi Eddi's Service, jednej z wersji The Looking-Glass, A St. Helen's Lullaby, L'Envoi czy The Gods of the Copybook Headings ${ }^{47}$. Przegląd tematyki już choćby tych kilku tekstów wybranych przez Rafalskiego pozwala dostrzec prawidłowość selekcji. Napisał je Kipling na początku XX wie$\mathrm{ku}$ i stanowiły wtedy poetyckie ostrzeżenia, pesymistyczne prognozy rozwoju zainicjowanych zaledwie zjawisk społeczno-kulturowych. Czytane dziś dotyczą, po pierwsze, istotnych już i rozwiniętych problemów ponowoczesnej cywilizacji, takich jak choćby kryzys religii (w Pasterce brata Eddiego oraz L'Envoi z incipitem „ołtarz wnet zaświeci pustką, / miast kwiatów i kadzideł - żal"48), negatywne rezultaty feministycznej rewolucji seksualnej (zwłaszcza w wersie wiersza Bogowie z zeszytów szkolnych: „niewiasty płodność straciły, a mężowie rozsądek i wiarę"49) tudzież skutki chybionych eksperymentów gospodarczych socjalizmu („przez wywłaszczenie wybranych, aby opłacić byt wspólny, / lecz choć pieniędzy nie brakło, nie było nic do nabycia" $\left.{ }^{\prime 0}\right)$. Po drugie natomiast,

${ }^{46}$ K. Rafalski, Kipling Interest in Poland, „Kipling Journal” 2006, vol. 80 (czerwiec), s. 25.

47 Odpowiednio w kolejnych numerach czasopisma „Akant”: 2005, nr 1; 2006, nr 1; nr 5; nr 7; 2007, nr 4. Warto wspomnieć również nowy wariant pieśni Mandalay w tłumaczeniu Kamili Erdmańskiej („Akant” 2008, nr 4).

48 R. Kipling, L'Envoi, tłum. K. Rafalski, „Akant” 2006, nr 7, s. 15.

49 R. Kipling, Bogowie z zeszytów szkolnych, tłum. K. Rafalski, „Akant” 2007, nr 4, s. 25.

50 Ibidem, s. 25. Oba przytoczone fragmenty w oryginale The Gods of the Copybook Headings brzmią: "on the first Feminian Sandstones we were promised the Fuller Life / (which started by loving our neighbour and ended by loving his wife) / till our women had no more children and the men lost 
uniwersalnych prawidłowości ludzkiego życia, jak niepowstrzymany upływ czasu i przemijająca młodość (wiersz Zimne zwierciadto ze znamiennym dwuwersem: „w zimnym zwierciadle już nie zagości / lico nadobne lat młodości”51) czy ponadczasowa ludzka nieumiejętność konsekwentnego czerpania doświadczeń i wyciągania wniosków z pamięci o popełnionych w przeszłości błędach:

W przyszłości tak się dziać będzie, jak od Rasy początków przedwiecznych: cztery są rzeczy pewne, wplątane w nasz postęp społeczny że pies do swych brudów powraca, a świnia w rodzime błoto, zaś głupca palec sparzony znów w ogień pcha się z ochotą ${ }^{52}$.

Te i inne obszary tematyczne liryków Kiplinga w wersjach Rafalskiego znajdują swoje odniesienie do współczesności nie tyle wskutek arbitralnej ingerencji tłumacza w komunikat, lecz samej aktualności oryginalnego tekstu.

Przykładem z kolei pragmatycznego podejścia do procesu przekładu jest sposób, w jaki felietonistyka polskich publicystów konserwatywno-liberalnych inkorporuje fragmenty lub całości liryków poety, a jego nazwisko pełni w ich wywodach funkcję wzmacniającego stawiane tezy autorytetu. Dobrze ilustruje tę praktykę artykuł ogłoszony w 2006 roku na łamach periodyku „Dziennik Polski” (a w 2008 przez serwis internetowy „Najwyższy Czas!”), w którym Janusz Korwin-Mikke krytycznie ocenia rządowe inicjatywy przeciwdziałania agresji „chuliganów futbolowych”. Jak bowiem stwierdza: metody ich zwalczania „są fragmentem antycywilizacji, którą buduje obecnie Lewica”, gdyż to „kibol-patriota”, w przypadku zagrożenia ojczyzny, „będzie bronił kobiet i dzieci”. Dla potwierdzenia użytej argumentacji i wzmocnienia perswazyjności myśli przewodniej tekstu publicysta dodaje: „śp. Rudyard Kipling, ten od Księgi Dżungli, pisał (tłumaczenie własne):

reason and faith” oraz „we were promised abundance for all, / by robbing selected Peter to pay for collective Paul / but, though we had plenty of money, there was nothing our money could buy".

${ }^{51}$ R. Kipling, Zimne zwierciadto, tłum. K. Rafalski, „Akant” 2006, nr 1, s. 11.

52 R. Kipling, Bogowie z zeszytów szkolnych, tłum. K. Rafalski, „Akant” 2007, nr 4, s. 25. 
„Franek jest durny!”, „Franek zły!”

i: „Zjeżdżaj stąd, psia mać!”

Lecz on się staje zbawcą, gdy

Armaty zaczną grać!" ${ }^{3}$.

Przywołany fragment jest w istocie przekładem dwóch linii z finalnej strofy wiersza Tommy: „for it's Tommy this, an' Tommy that, an' »Chuck him out, the brute! $\ll /$ but it's $\gg$ Saviour of 'is country $\ll$ when the guns begin to shoot”. Od semantyki oryginału różni go zwłaszcza jeden istotny detal - wraz ze zmianą imienia podmiotu lirycznego i wyjęciem dwuwersu z kontekstu pozostałych części utworu, usunięta zostaje niebagatelna informacja o profesji bohatera. W rezultacie ustęp $\mathrm{z}$ wiersza o niesprawiedliwości spotykającej kolonialnego żołnierza brytyjskiego ze schyłku XIX wieku okazuje się w równej mierze dotyczyć współczesnych, polskich bohaterów felietonu tłumacza i ich społecznego postrzegania.

Zbliżony przykład - tym razem jednak dotyczący nie fragmentu, lecz całości tekstu - stanowić może The Female of the Species, przełożony przez Roberta Stillera jako Samica swego gatunku dla tego samego periodyku ${ }^{54}$. Krytyczna wobec aktualnych kierunków rozwoju ideologii feministyczno-genderowej linia programowa czasopisma i publikowane w nim artykuły współgrają z wymową wiersza. Kipling bowiem, wyliczając różnice charakterologiczne między kobietami a mężczyznami, wskazuje na zgodne z naturą ukonstytuowanie ich tradycyjnych ról społecznych. Przekład Stillera nie tylko skrupulatnie oddaje oryginalną listę przymiotów obu płci, ale dodatkowo jeszcze rozszerza katalog kobiecych przywar. Strofę, na przykład, porównującą zachowanie zwierząt do obyczajów ludzkich:

53 J. Korwin-Mikke, Kastrowanie obrońców, „Dziennik Polski”, 16.06.2006 (cyt. za: „Najwyższy Czas!”, wersja dostępna on-line od 8 stycznia 2008 na oficjalnej stronie tygodnika: www.nczas.com/publicystyka/korwin-mikke-kastrowanie-obroncow/; dostęp: 10.04.2017).

${ }^{54}$ R. Kipling, Samica swego gatunku, tłum. R. Stiller, „Najwyższy Czas!” 2005, nr 11, s. XXXVII. Warto dodać, że w kontekście tego akurat numeru czasopisma wiersz Kiplinga nabiera wymowy bardziej satyrycznej - wraz z datą wydania (tygodnik wydrukowano tuż po 8 marca 2005) i zamieszczeniem go w rubryce zatytułowanej „Dzień Kobiet”. 
When Nag the basking cobra hears the careless foot of man, He will sometimes wriggle sideways and avoid it if he can.

But his mate makes no such motion where she camps beside the trail.

For the female of the species is more deadly than the male.

przedstawia tłumacz czytelnikom polskim jako:

Krok niebacznej stopy słysząc, grzejąca się w słońcu kobra Odczołga się nieraz w bok, bo zgoda też bywa dobra.

Ale jeśli to samica, nie popuści jej wścieklica.

Gdyż od samca dużo bardziej śmiercionośną jest samica

Jeden zaś z refrenowo powtarzalnych wersów „the female of the species must be deadlier than the male" modyfikuje Stiller do postaci: kobieta „po to jest od samca bardziej śmiercionośna, groźna, podła”. Wprawdzie ani agresywnego braku samokontroli („wścieklica”), ani „podłości” czy szczególnej inklinacji do budzenia grozy Kipling rodzajowi żeńskiemu w oryginale nie przypisuje, lecz ingerencje translatorskie tego typu jedynie wzmacniają finalną, zgodną z konserwatywnym światopoglądem brytyjskiego poety i profilem polskiego czasopisma konkluzję wiersza: „Mężczyzna wie, że kobieta, przez Boga mu powierzona, / żądać ma, nie rządzić i rozpalać, nie zniewalać” („Man [...] knows, moreover, that the Woman that God gave him / must command but may not govern - shall enthral but not enslave him") ${ }^{55}$. Podobnych ujęć liryków noblisty może czytelnik polskiej publicystyki polityczno-społecznej znaleźć więcej ${ }^{56}$.

***

55 Ibidem, s. XXXVII.

${ }^{56}$ Warto też wspomnieć o przekładach wierszy Kiplinga, tematycznie dotyczących wolnomularstwa, które wykonane zostały w ostatniej dekadzie dla stron internetowych i periodyków poświęconych tej tematyce - jak na przykład tłumaczenie liryku The Mother-Lodge (Matka-Loża, tłum. E. Kaczmarek, „Ars Regia. Czasopismo poświęcone myśli i historii wolnomularstwa” 2010, nr 19, s. 339-341). 
Nawet tak pobieżny i z konieczności szkicowy jedynie przegląd historii recepcji przekładowej i czytelniczej poezji Rudyarda Kiplinga pozwala sformułować dwa wnioski. Po pierwsze, w każdej z polskich epok historycznoliterackich od modernizmu do ścisłej współczesności utwory liryczne pisarza - niezależnie od sposobu wartościowania ujętego w nich przesłania i ideologii - były i są postrzegane jako zdolne do prowadzenia inspirującego dialogu z aktualnymi dyskursami kulturowymi. Po drugie, sama możliwość nawiązania takiego dialogu jest efektem nie tylko nieprzeciętnej witalności refleksji Kiplinga, ale także translatorskiej ingerencji w treść i formę, która ją transmituje. Przekład jest więc w tym przypadku zarówno środkiem ustanawiającym komunikację między brytyjskim autorem a polskim czytelnikiem, jak i medium pozwalającym na jej ukierunkowanie i niejednokrotnie daleko posuniętą kontrolę.

\section{Bibliografia}

Balcerzan E., Rajewska E. (red.), Pisarze polscy o sztuce przekładu 14402005. Antologia, Wydawnictwo Poznańskie, Poznań 2007.

Baran-Szymańska M., Kipling nieznany, „Akant” 2007, nr 1.

Bhabha H., Miejsca kultury, tłum. T. Dobrogoszcz, Wydawnictwo Uniwersytetu Jagiellońskiego, Kraków 2010.

Bogomilska K., Rudyard Kipling - twórca omamiony imperializmem, „Gazeta Polska” 1996, nr 3.

Chwalewik W., Rudyard Kipling w świecie dzisiejszym, [w:] Europejskie związki literatury polskiej, red. J. Jakubowski, Państwowe Wydawnictwo Naukowe, Warszawa 1969.

Czechowicz J., Przekłady, red. W. Kruszewski, D. Pachocki, Wydawnictwo Uniwersytetu Marii Curie-Skłodowskiej, Lublin 2011.

Davies N., Wyspy, tłum. E. Tabakowska, Znak, Kraków 2012.

Dyboski R., Sto lat literatury angielskiej, Instytut Wydawniczy Pax, Warszawa 1957.

Easterly W., Brzemię białego człowieka, tłum. E. Łyszkowska, Wydawnictwo Naukowe PWN, Warszawa 2008.

Eliot T.S., Szkice literackie, tłum. W. Chwalewik i in., Instytut Wydawniczy Pax, Warszawa 1963. 
Ferguson N., Imperium. Jak Wielka Brytania zbudowata nowoczesny świat, tłum. B. Wilga, Wydawnictwo Literackie, Warszawa 2007.

Fiktus P., „Nowa Polska” w polskiej myśli kolonialnej do 1939, [w:] Prace z myśli polityczno-prawnej oraz prawa publicznego, red. M. Sadowski, P. Szymaniec, Wydział Prawa, Administracji i Ekonomii Uniwersytetu Wrocławskiego, Wrocław 2012.

Floryan W. (red.), Dzieje literatur europejskich, t. 2, Państwowe Wydawnictwo Naukowe, Warszawa 1982.

Gandhi L., Teoria postkolonialna. Wprowadzenie krytyczne, tłum. J. Serwański, Wydawnictwo Poznańskie, Poznań 2008.

Gronau J., Wędrówki po bibliografii angielskiego autora Rudyarda Kiplinga, Kraków 2007.

Helsztyński S., Liryka angielska XX wieku, Warszawa 1929.

Jakubowski J. (red.), Europejskie związki literatury polskiej, Państwowe Wydawnictwo Naukowe, Warszawa 1969.

Jarniewicz J., Tytut $w$ przekładzie, [w:] Pisarze polscy o sztuce przekładu 1440-2005. Antologia, red. E. Balcerzan, E. Rajewska, Wydawnictwo Poznańskie, Poznań 2007.

Jekutsch U., Sulikowski A. (red.), Poezja polska i niemiecka $w$ przekładach współczesnych, PPH Zapol Dmochowski, Sobczyk, Szczecin 2002.

Kasprowicz J., Dzieła, red. S. Kołaczkowski, t. I, VII, IX, Kraków 1930.

Kipling R., Bogowie z zeszytów szkolnych, tłum. K. Rafalski, „Akant” 2007, nr 4.

Kipling R., Complete Collection of Poems by Rudyard Kipling, www.poetryloverspage.com /poets/kipling (dostęp: 20.04.2017).

Kipling R., Kołysanka świętej Heleny, tłum. K. Rafalski, „Akant” 2006, nr 5. Kipling R., Księga dżungli, tłum. J. Birkenmajer, Nasza Księgarnia, Warszawa 1971.

Kipling R., L'Envoi, tłum. K. Rafalski, „Akant” 2006, nr 7.

Kipling R., Mandalay, tłum. K. Erdmańska, „Akant” 2008, nr 4.

Kipling R., Matka-Loża, tłum. E. Kaczmarek, „Ars Regia. Czasopismo poświęcone myśli i historii wolnomularstwa” 2010, nr 19.

Kipling R., Pasterka brata Eddiego, tłum. K. Rafalski, „Akant” 2005, nr 1.

Kipling R., Pod niebem indyjskim. Wybór noweli, tłum. A. Gawrońska, Księgarnia H. Altenberga, Lwów 1905.

Kipling R., Samica swego gatunku, tłum. R. Stiller, „Najwyższy Czas!” 2005, nr 11.

Kipling R., Stalky i spółka, tłum. J. Birkenmajer, Czytelnik, Warszawa 1978. Kipling R., Zimne zwierciadło, tłum. K. Rafalski, „Akant” 2006, nr 1. 
Kokot J., Takie sobie „bajeczki”. Gry z czytelnikiem w nowelistyce R. Kiplinga, Wydawnictwo Gdańskie, Gdańsk 1993.

Kokot J., Tekst w tekście. Studia o wierszu w prozie narracyjnej, Gdańsk 1992. Kornhauser J., Polityka i przekład. O dwóch antologiach liryki niemieckiej, [w:] Poezja polska i niemiecka w przekładach wspótczesnych, red. U. Jekutsch, A. Sulikowski, PPH Zapol Dmochowski, Sulik, Szczecin 2002.

Korwin-Mikke J., Kastrowanie obrońców, „Dziennik Polski”, 16.06.2006 („Najwyższy Czas!”, wersja dostępna od 01.2008 on-line: www.nczas. com/publicystyka/korwin-mikke-kastrowanie-obroncow/; dostęp: 20.04.2017).

Kowalski M.A., Kolonie Rzeczypospolitej, Bellona, Warszawa 2005.

Kozarynowa Z. (ps. Rębajło), Nieznany Kipling, nieznany Kasprowicz, „Dziennik Polski i Dziennik Żołnierza” 1984, nr 46.

Krajewska W., Recepcja literatury angielskiej $w$ Polsce $w$ okresie modernizmu, Ossolineum, Wrocław 1972.

Krzeczkowski H. (red.), Poeci języka angielskiego, t. 3, Państwowy Instytut Wydawniczy, Warszawa 1974.

Lenin W., Imperializm jako najwyższe stadium kapitalizmu, tłum. J. Górski, Książka i Wiedza, Warszawa 1980.

Łuszczykiewicz A., „Psalmista szowinizmu”. Rudyarda Kipling wobec Indii i Indusów, Silva Rerum, Poznań 2014.

Maurois A., Magicy i logicy. Szkice o pisarzach angielskich, tłum. E. Bąkowska, W. Lewik, Czytelnik, Warszawa 1959.

Miłosz C., Kontynenty, Znak, Kraków 1999.

Nowaczyński A., Szkice literackie, Poznań 1918.

Pietrkiewicz J., Antologia liryki angielskiej 1300-1950, Instytut Wydawniczy Pax, Warszawa 1957.

Pollak S. (red.), Przekład artystyczny, t. 2, Ossolineum, Wrocław 1975.

Rafalski K., Kipling Interest in Poland, „Kipling Journal” 2006, vol. 80 (czerwiec).

Sadowski M., Szymaniec P. (red.), Prace z myśli polityczno-prawnej oraz prawa publicznego, Wydział Prawa, Administracji i Ekonomii Uniwersytetu Wrocławskiego, Wrocław 2012.

Said E., Kultura i imperializm, tłum. M. Wyrwas-Wiśniewska, Wydawnictwo Uniwersytetu Jagiellońskiego, Kraków 2009.

Stiller R. (red.), Strofy o zwierzętach, Iskry, Warszawa 1982.

Stiller R. (red.), Strofy z dreszczykiem, Iskry, Warszawa 1986.

Waśkiewicz K. (red.), Poeci nobliści 1901-1993, Anagram, Warszawa 1994. 
Zaleski M., Kipling i Conrad: spojrzenie z dwóch kątów imperium, „Res Publica Nowa” 2005, nr 4.

Zbierski H., Literatura angielska, [w:] Dzieje literatur europejskich, red. W. Floryan, t. 2, Państwowe Wydawnictwo Naukowe, Warszawa 1982. Żuliński L. (red.), Laurowo i jasno: antologia wierszy laureatów literackiej $\mathrm{Na}$ grody Nobla, Wydawnictwo Bohdana Wrocławskiego, Warszawa 1994. Żuławski J., O tłumaczeniu ksiag, [w:] Przekład artystyczny, red. S. Pollak, t. 2, Ossolineum, Wrocław 1975. 